\title{
Observations of Seiching and Tides Around the Islands of Mauritius and Rodrigues
}

\author{
R. Lowry', D. T. Pugh², E. M. S. Wijeratne ${ }^{3}$ \\ ${ }^{1}$ Mauritius Oceanography Institute, DPI, Western Australia; ${ }^{2}$ National Oceanography Centre, Southampton, \\ UK, Proudman Oceanographic Laboratory, Merseyside, UK, ${ }^{3}$ Oceanography Division, NARA, Sri Lanka.
}

\begin{abstract}
Keywords: Seiching, tides, Mauritius, Rodrigues, Indian Ocean
Abstract-Short-period sea level changes around the islands of Mauritius and Rodrigues in the central Indian Ocean have been analysed to determine the favoured seiche periods. The largest amplitudes are found inside the harbours of Port Louis, Mauritius (7 and 20 minutes) and Port Mathurin, Rodrigues (25 minutes), but these amplitudes are much smaller just outside the harbours, and the characteristic periods are found only locally, confirming that local topography controls the periods of the seiching. The extent and energising of these seiching phenomena calls for further investigation. Associated seiche currents, potentially much stronger than tidal currents, could influence harbour shipping movements. Analysis of the sea level data showed that there are significant spatial variations in the amplitudes and phases of the tides around Mauritius Island, but the around-island tidal variations are much smaller for Rodrigues Island.
\end{abstract}

\section{INTRODUCTION}

Seiching is the oscillation of bodies of water at natural periods, controlled by the depth and horizontal dimensions of those bodies. Short period oscillations of sea level are commonly observed at coastal locations around many oceanic islands, including and perhaps, especially, in the Indian Ocean. These oscillations can have periods lasting a few minutes to more than an hour, and amplitudes sometimes greater than $0.2 \mathrm{~m}$. As an example, at Mahe in the Seychelles oscillations of periods of 10 and 50 minutes were found to be superimposed on the larger tidal oscillations of sea level (Pugh, 1979),. The 10-minute period oscillations were found to be correlated with the wind speed, but no correlation was found between the 50-minute oscillations and any possible forcing mechanisms. At Mombasa, on the Kenyan coast no seiching was observed; but seiching was clearly observed at Aldabra Atoll, a coral island about 1,000 km southeast of the Seychelles main island group. At Aldabra, periods from 25 to 50 minutes were recorded, intermittently from October to May, when they persisted from two to 14 days. Shorter period seiching at Aldabra with periods from 3 to 5 minutes, were correlated with high swell, reaching a maximum between June and August, the season for maximum Southern Ocean storms, and may have been due to surf beat phenomena (Pugh, 1979).

In the eastern Indian Ocean, along western coast of Australia, oscillations at non-tidal frequencies are well documented (for example, Morison and Imberger, 1992). Oscillations of about 1-3 minutes are known to occur at Esperance, where they have caused excessive motion of moored ships and are attributed to set down of swell waves beneath wavegroups (Morison and Imberger, 1992). At Busselton and Geraldton, oscillations of 4 hours are known to occur due to resonance determined by the shelf width. The same phenomenon occurs at Jurien and Fremantle but the frequency of oscillation 
is 2.7 hours. The higher frequency oscillation, compared to those of Busselton and Geraldton, is due to the decrease in shelf width at these locations (Pattiaratchi and Wijeratne, in prep). A predominant period of oscillation of 30 minute was also found to occur on the shelf between Geraldton and Perth due to the channel formed by the shore and a submerged reef chain. For this seiche, the estimated resonance has a ten-fold amplification up the channel. This oscillation is found to have significant diurnal and seasonal correlation (Allison and Grassia, 1979).

Interest in the characteristics of seiching has been renewed recently, following the 26 December 2004 Sumatra tsunami. Rabinovich and Thomson (2007) have looked at the seiche characteristics of many Indian Ocean sea level sites, under conditions of the extreme tsunami forcing, but at many sites smaller amplitude seiching is a continual occurrence.

Seiches have been explained in terms of quarterwave resonance between the coastal wave-reflecting barrier, and a bathymetry break to deeper ocean water (Chapman and Giese, 1990; Giese et al., 1990; and the general account of seiches by Giese and Chapman, 1993). The present study investigates these possibilities and characterises the seiching around the islands of Mauritius and Rodrigues, as shown in Figure 1.

\section{MEASUREMENTS}

This study made measurements of seabed pressure using recording gauges manufactured by RBR Ltd. the Canadian oceanographic instrumentation company. All gauges were RBR-1050 types with 50-metre pressure sensors, and manufacturer's specified characteristics as follows:

Accuracy $+/-0.05 \%$ of full scale $(0.025 \mathrm{~m})$ Resolution $0.001 \%$ of full scale $(0.0005 \mathrm{~m})$.

Experience with these gauges (Araujo, 2005) confirms their stability to $0.01 \mathrm{~m}$ over a period of several days, mindful that for seiche analyses absolute accuracy is not important. All gauges were set to record in Greenwich Mean Time (GMT) on the hour and at 6-minute intervals. Instrument sensitivity is estimated to be better than $1 \%$, and the timing accuracy against GMT is better than +/- two minutes.

The RBR-1050 gauges measure absolute pressure, which was then converted to sea level heights using the appropriate seawater density values. Changes in atmospheric pressure, which would also appear in the measured signals unless compensated for by an "inverse barometer" response in the sea levels, are very small (amplitude equivalent to approximately $0.01 \mathrm{~m}$ sea level) at the frequencies of interest in this study. Even the

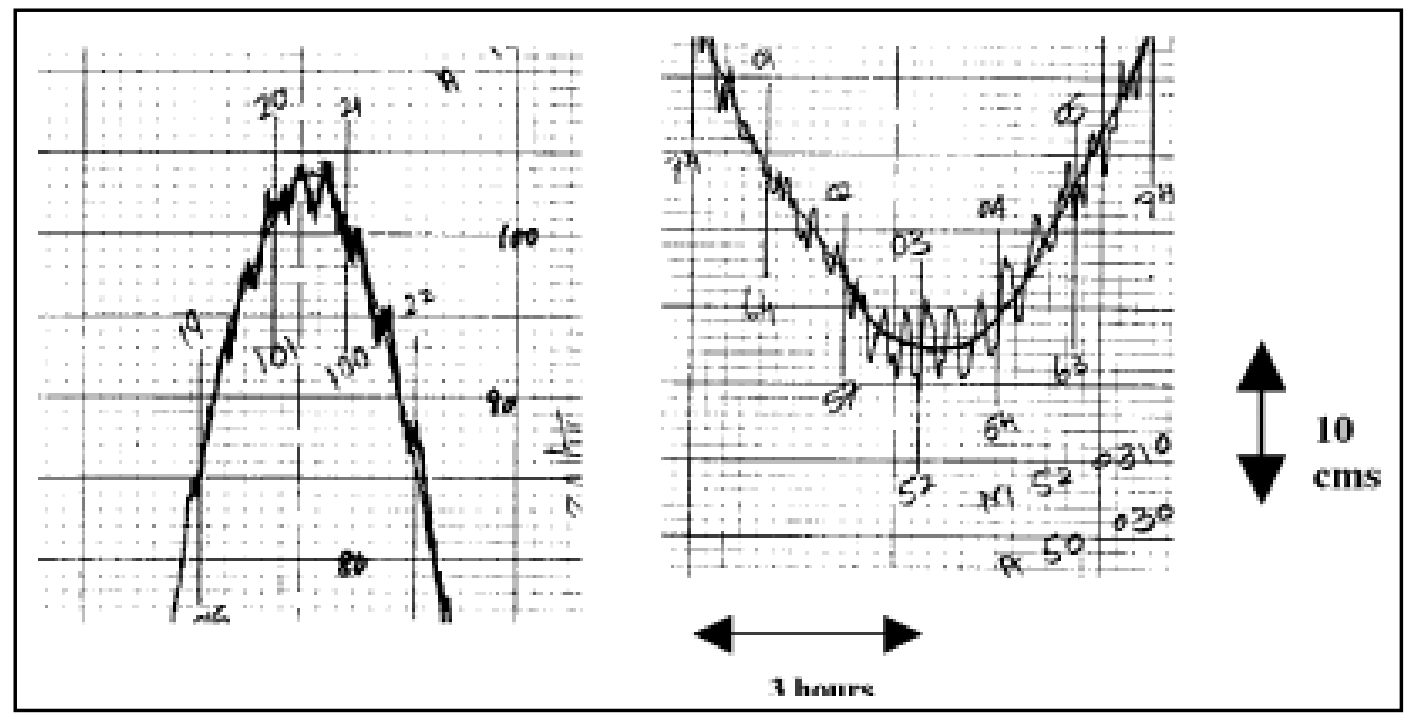

Fig. 1. Old analogue chart records of sea level seiches at Port Mathurin (left) and Port Louis (right) from 30-31 March 1999. Source: Mauritius Meteorological Services 
$\mathbf{S}_{2}$ atmospheric tidal term, which has an amplitude of $1.25 \cos ^{3}$ (latitude) hPascals (Chapman and Lindzen, 1970), is negligible at these latitudes, with a sea level equivalent of $0.01 \mathrm{~m}$.

In addition, some sea level data were obtained from the permanent Intergovernmental Oceanographic Commission, Global Sea Level Observing System (GLOSS), network gauges at Port Louis and Port Mathurin, through the University of Hawaii (http://ilikai.soest.hawaii. edu/uhslc/datai.html). GLOSS gauges have a target accuracy of better than $0.01 \mathrm{~m}$ (Woodworth et al., 2003).

Two short periods of intensive recordings were made in turn, around the two islands using the RBR gauges, in July 2002. The sites are shown in Figures 2, 3 and 4 and the locations are given in Table 1. The short periods of simultaneous measurements in July 2002 were all subjected to spectral analysis, after removing tidal sea level variations.
Some of the longer records from the RBR pressure gauges can be analysed using standard onemonth or longer tidal programmes. The Proudman Oceanographic Laboratory TIRA programme (http://www.nerc-liv.ac.uk/psmsl/training/task2k. $\mathrm{html}$ ) was used to analyse tidal records from outside the harbours at Port Louis and at Port Mathurin, and also outside and inside Blue Bay. For Port Louis and for Port Mathurin, one year of data (2002) from the GLOSS permanent gauges obtained through the University of Hawaii, were analysed. Calibrations and time settings suggest an accuracy of $1 \%$ in amplitudes and 2 minutes in timing.

\section{SEICHES}

The short-term period at Mauritius was about 63 hours; at Rodrigues it was 121 hours except for the gauge at Passe Grande Basin, where the final five hours were lost due to file corruption.

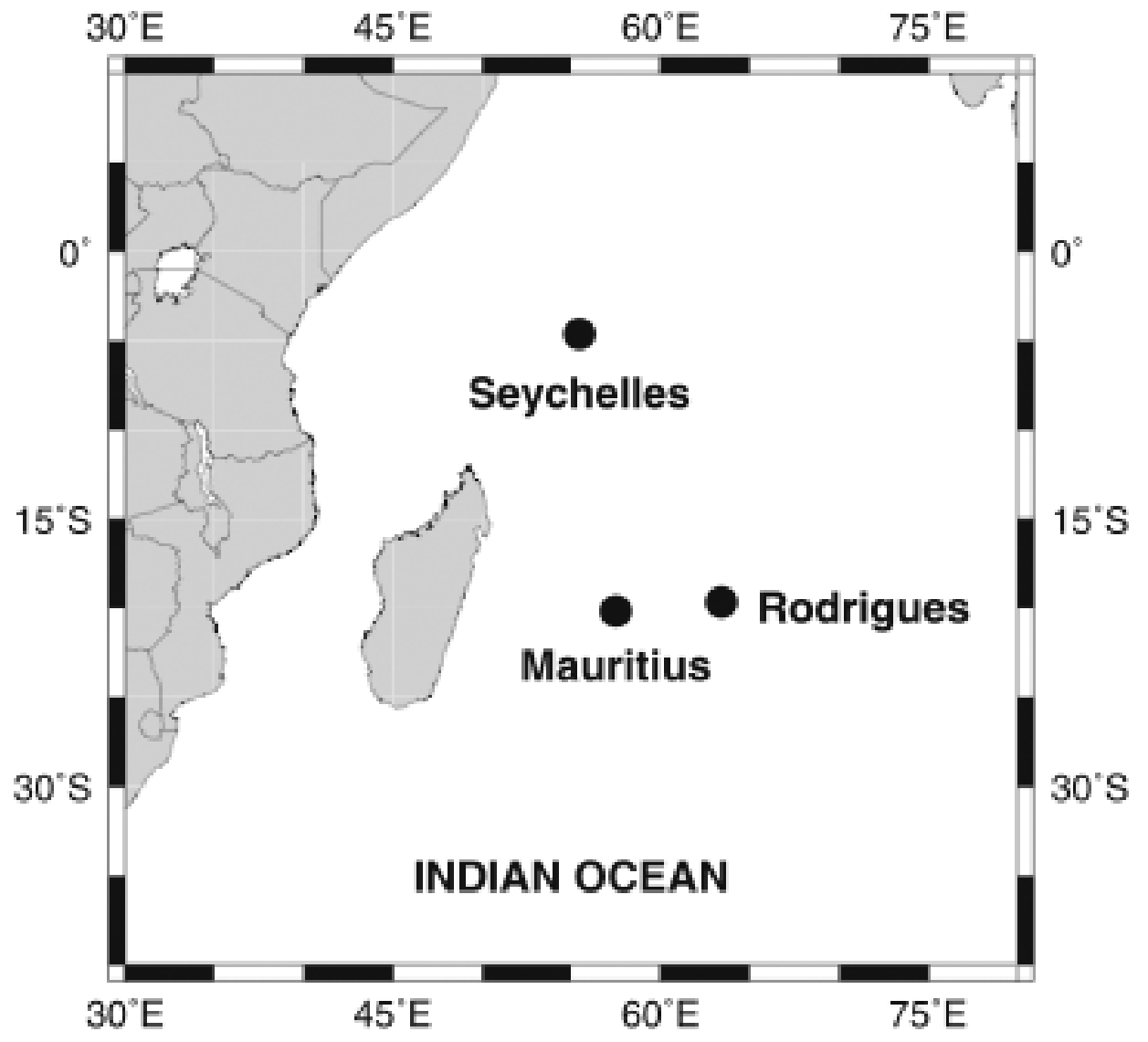

Fig. 2. General location map for the Western Indian Ocean 


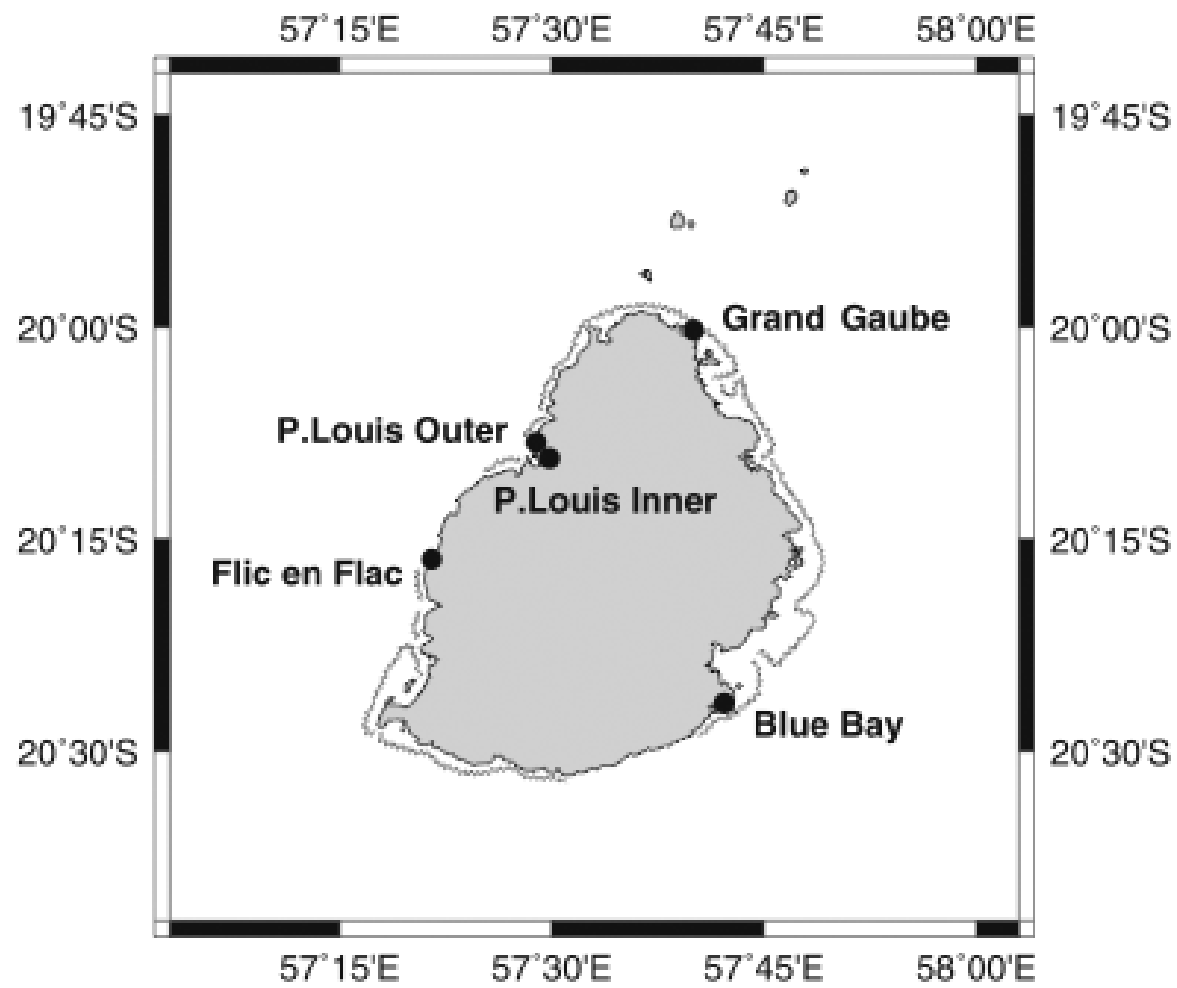

Fig. 3. Location of measurement sites on the island of Mauritius

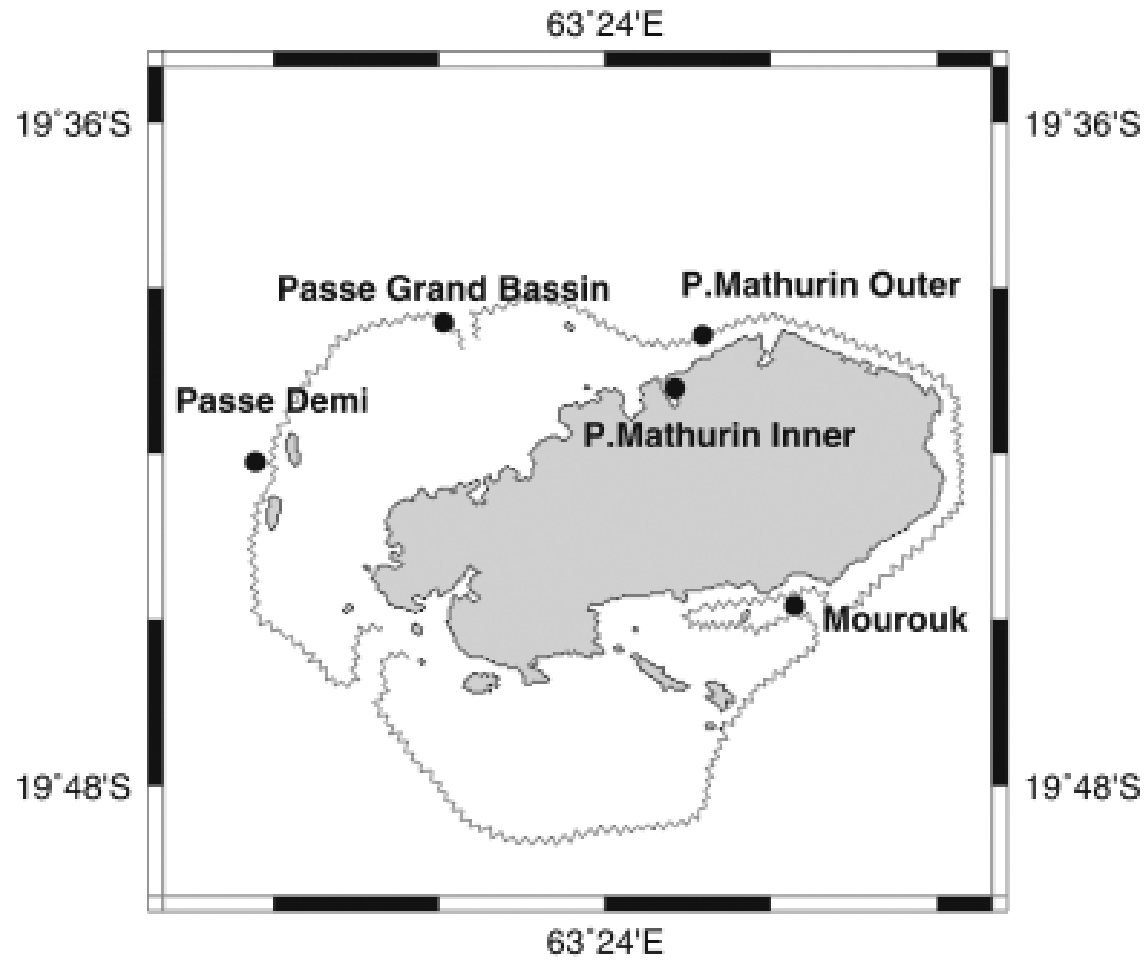

Fig. 4. Location of measurement sites on the island of Rodrigues 
Table 1. Location of sea level measurments

\begin{tabular}{lll}
\hline Mauritius & Latitude & Longitude \\
\hline Blue Bay inner & $20^{\circ} 26.6$ 'S & $57^{\circ} 42.2^{\prime} \mathrm{E}$ \\
Blue Bay outer & $20^{\circ} 27.2^{\prime} \mathrm{S}$ & $57^{\circ} 42.5^{\prime} \mathrm{E}$ \\
Grand Gaube & $20^{\circ} 0.2^{\prime} \mathrm{S}$ & $57^{\circ} 40.0^{\prime} \mathrm{E}$ \\
Port Louis Harbour Beacon (outer) & $20^{\circ} 8.15^{\prime} \mathrm{S}$ & $57^{\circ} 28.9^{\prime} \mathrm{E}$ \\
Port Louis Fanfaron (inner) & $20^{\circ} 9.25^{\prime} \mathrm{S}$ & $57^{\circ} 29.85^{\prime} \mathrm{E}$ \\
Flic en Flac & $20^{\circ} 16.4^{\prime} \mathrm{S}$ & $57^{\circ} 21.5^{\prime} \mathrm{E}$ \\
& & \\
Rodrigues & & \\
Passe Demi & $19^{\circ} 42.14$ 'S & $63^{\circ} 17.68^{\prime} \mathrm{E}$ \\
Passe Grand Basin & $19^{\circ} 39.62 ' \mathrm{~S}$ & $63^{\circ} 21.07^{\prime} \mathrm{E}$ \\
Port Mathurin (outer) & $19^{\circ} 40.19^{\prime} \mathrm{S}$ & $63^{\circ} 25.76^{\prime} \mathrm{E}$ \\
Port Mathurin (inner) & $19^{\circ} 40.82^{\prime} \mathrm{S}$ & $63^{\circ} 25.26^{\prime} \mathrm{E}$ \\
Mourouk & $19^{\circ} 44.75^{\prime} \mathrm{S}$ & $63^{\circ} 27.43^{\prime} \mathrm{E}$ \\
\hline
\end{tabular}

These short-period measurements were followed by longer periods of measurements at selected points, particularly outside the main harbours, as summarised in Tables $2 \mathrm{a}$ and $2 \mathrm{~b}$.

Figure 5 shows the spectral plots for the five sites around Mauritius Island. There are clear seiches at periods of both 20 minutes and 7 minutes at Port Louis inner harbour, and seiches of period around 32 minutes at Grand Gaube. There are no other systematic seiche periods above the one standard deviation confidence level at the other sites.

For Rodrigues, the short period of simultaneous data has been analysed as shown in Figure 6. Here the main seiching is within the harbour at Port Mathurin, with a period of 25 minutes. There are also seiches, with period of about 18 minutes at Passe Demi. Outside Port Mathurin harbour there are indications of smaller seiches at the same 25-

Table 2a. Periods of measurements at Mauritius (PL is Port Louis)

\begin{tabular}{lll}
\hline Location & Start of file & End of file \\
\hline Detailed short-term Mauritius & 10 Jul 2002 @ 11:00 & 13 Jul 2002 @ 02:59 \\
Long Term- PL outer & 5 Aug 2002 @ 10:30 & 17 Sep 2002 @ 07:12 \\
Long Term-PL outer & 17 Sep 2002 @ 07:26 & 22 Oct 2002@ 06:022 \\
Long Term - PL inner & 22 Oct 2002@ 08:00 & 31 Jan 2003 @ 07:30 \\
Long Term - PL inner & 12 Dec 2002 @08:48 & 27 Mar 2003@ 07:20 \\
& & \\
Long Term - Blue Bay in Lagoon & 9 Aug 2002 @ 08:06 & 18 Oct 2002@ 06:46 \\
Long Term -Blue Bay in Lagoon & 18 Oct 2002 @ 08:08 & 12 Dec 2002 @ 07:14 \\
Long Term -Blue Bay in Lagoon & 12 Dec 2002 @ 08:15 & 30 Jan 2003 @ 07:13 \\
Long Term-Blue Bay outside lagoon & 12 Dec 2002 @ 07:00 & 30 Jan 2003 @ 06:40 \\
\hline
\end{tabular}

Table $2 b$. Periods of measurements at Rodrigues

\begin{tabular}{lll}
\hline Location & Start of file & End of file \\
\hline Detailed short-term Rodrigues & 17 Jul 2002 @ 05:45 & 22 Jul 2002 @ 04:44 \\
Long-term: & & \\
Outside Port Mathurin Harbour & 27 Jul 2002@ 05:30 & 28 Oct 2002@ 06:00 \\
Outside Port Mathurin Harbour & 28 Oct 2002 @ 06:30 & 11 Feb 2003 @ 10:10 \\
Outside Port Mathurin Harbour & 25 Feb 2003 @ 12:00 & 24 Mar 2003 @ 12:00 \\
Outside Port Mathurin Harbour & 24 Mar 2003 @ 13:00 & 16 May 2003 @ 07:40 \\
\hline
\end{tabular}




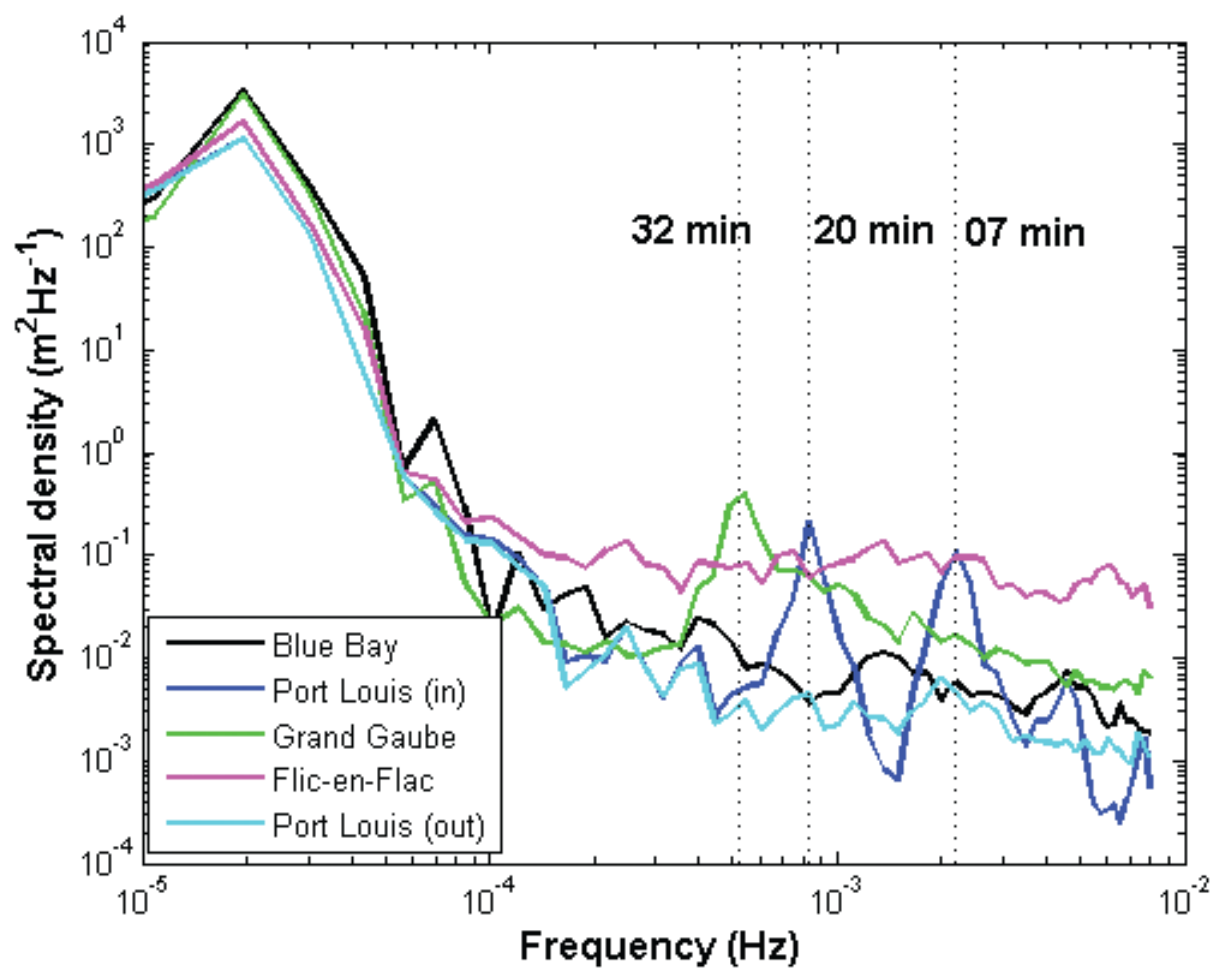

Fig. 5. Spectrum of seiches around the island of Mauritius 10-13 July 2002

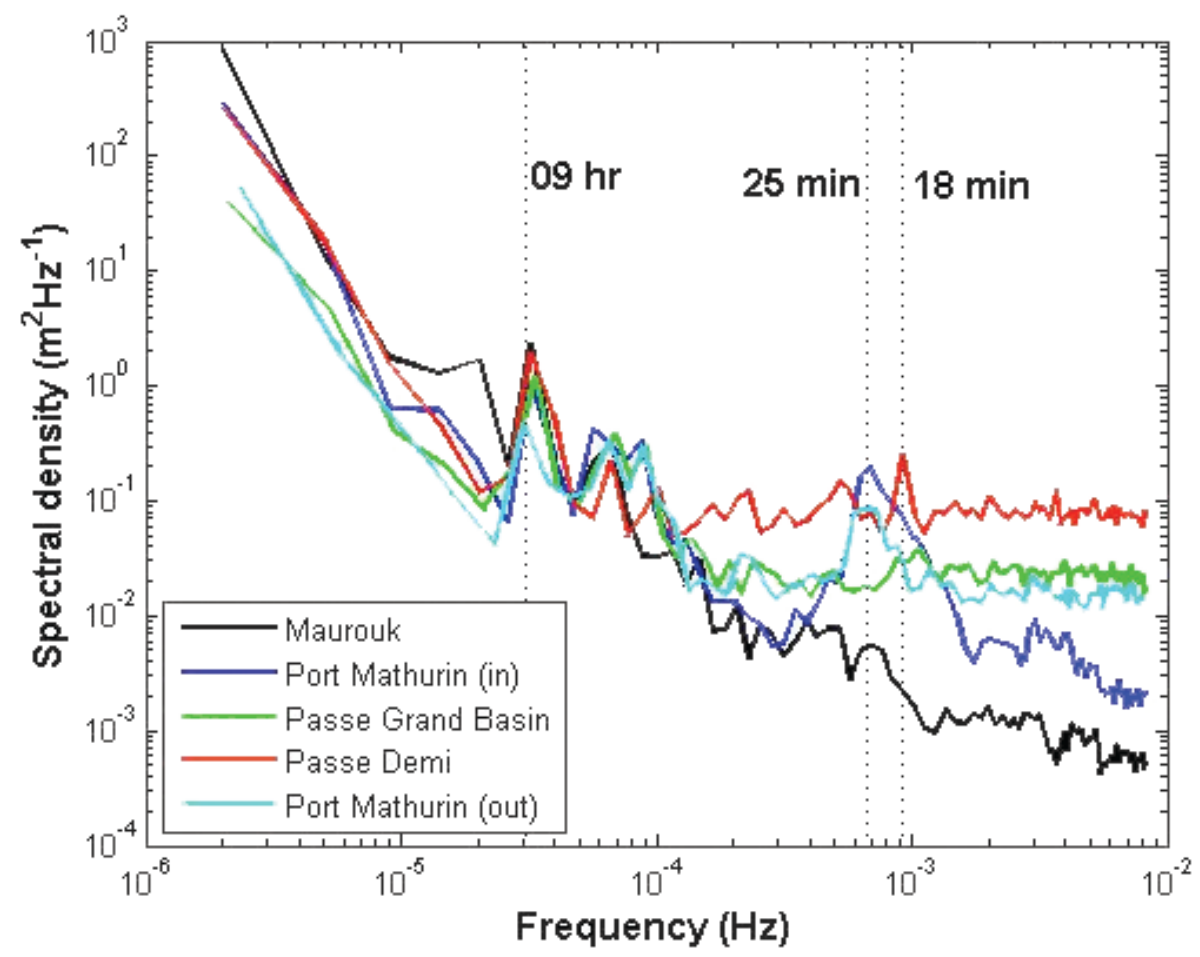

Fig. 6. Spectrum of seiches around the island of Rodrigues from 17 to 22 July 2002 
Table 3. Seiche periods for spectral peaks significant above one standard deviation

\begin{tabular}{lll}
\hline Mauritius & $\begin{array}{l}\text { Port Louis Inner } \\
\text { Grand Gaube }\end{array}$ & $\begin{array}{l}7 \text { and } 20 \text { minutes } \\
32 \text { minutes }\end{array}$ \\
Rodrigues & Port Mathurin Inner & 25 minutes \\
& Passe Demi & 18 minutes \\
\hline
\end{tabular}

minute period as inside the harbour. These seiche periods are summarised in Table 3.

Figures 7 and 8 show in more detail and over longer periods, the time variations of the spectra at Port Louis (2002) and Port Mathurin (2007). Both are inner harbours and reveal that the seiching at the expected periods are persistent throughout the longer records, though with some discernable variation in intensity. There is no evidence for a spring-neap dependence of tidal amplitude variation, at Port Louis, but the data from Port Mathurin does show some evidence, as discussed below.

The Port Mathurin data for 2007 has also been analysed seasonally, as shown in Figure 9. Seiches are persistent throughout the year, but amplitudes are slightly greater in July-August, and slightly less in November-December. A year of intermittent Port Louis data showed no seasonal variations.

There is also a dependence on the time of day in the amplitudes of the Port Mathurin seiches, as shown in Figure 10. This is most apparent in July and August, with maximum amplitudes around 0400-0600 and 1600-1800 GMT, which is around 0900 and 2100 local time.

\section{TIDES}

The results for the principal tidal harmonic components are summarised in Table 4 and show that the tides are mainly semidiurnal, as they are generally in the global ocean. At both islands, the ratio between the between the principal lunar semidiurnal tide $\left(\mathrm{M}_{2}\right)$ and the principal solar semidiurnal tide $\left(\mathrm{S}_{2}\right)$ amplitudes $\left(\mathrm{S}_{2} / \mathrm{M}_{2}=0.65\right.$ at Port Louis, and 0.64 at Port Mathurin) is greater than in the astronomical Equilibrium Tide (0.46). This is due to the relative proximity of anti-amphidromes in the south central Indian Ocean. In turn this means that the ratio between spring tidal ranges and neap
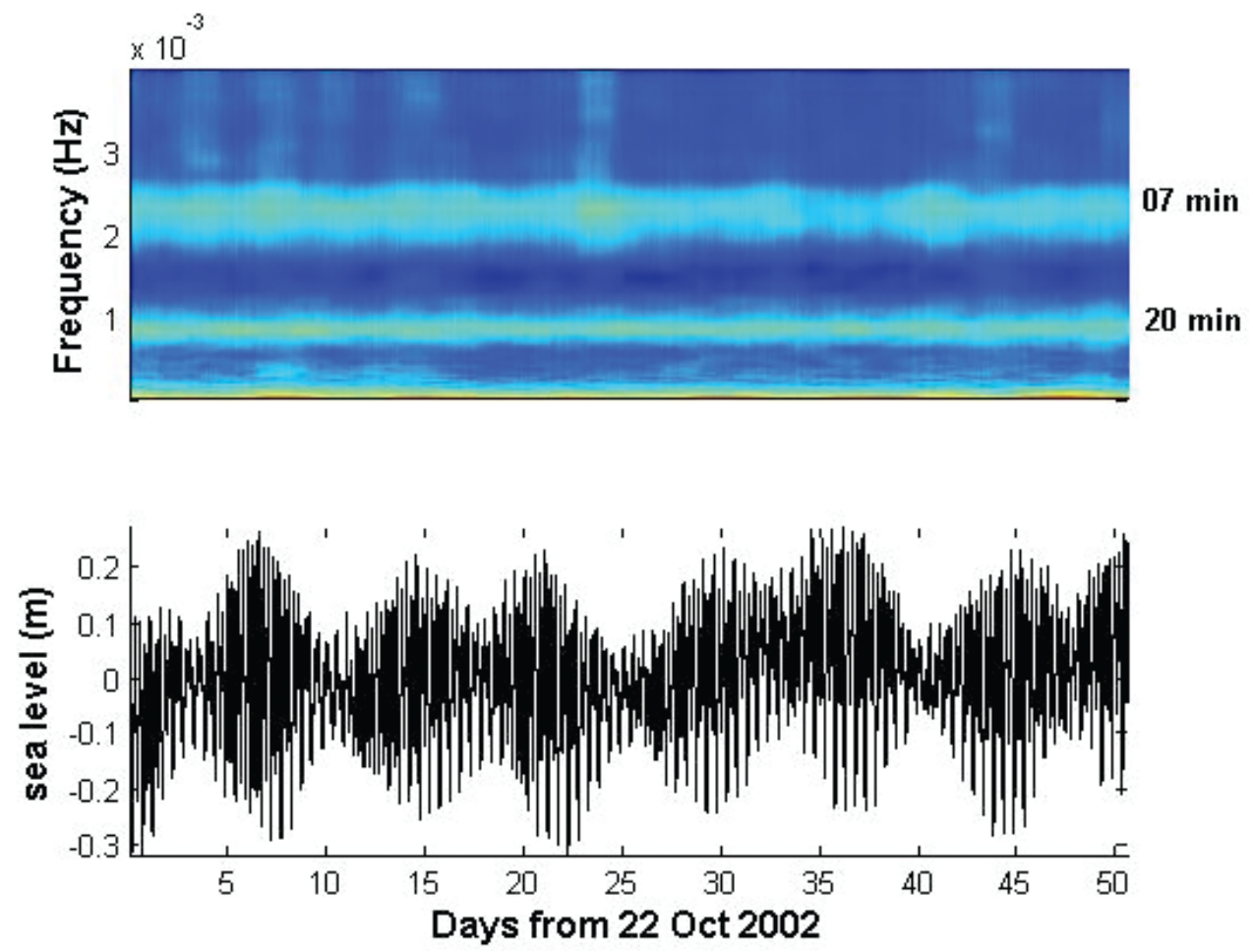

Fig. 7 . Time-spectrum plot for Port Louis inner harbour Oct-Dec 2002 

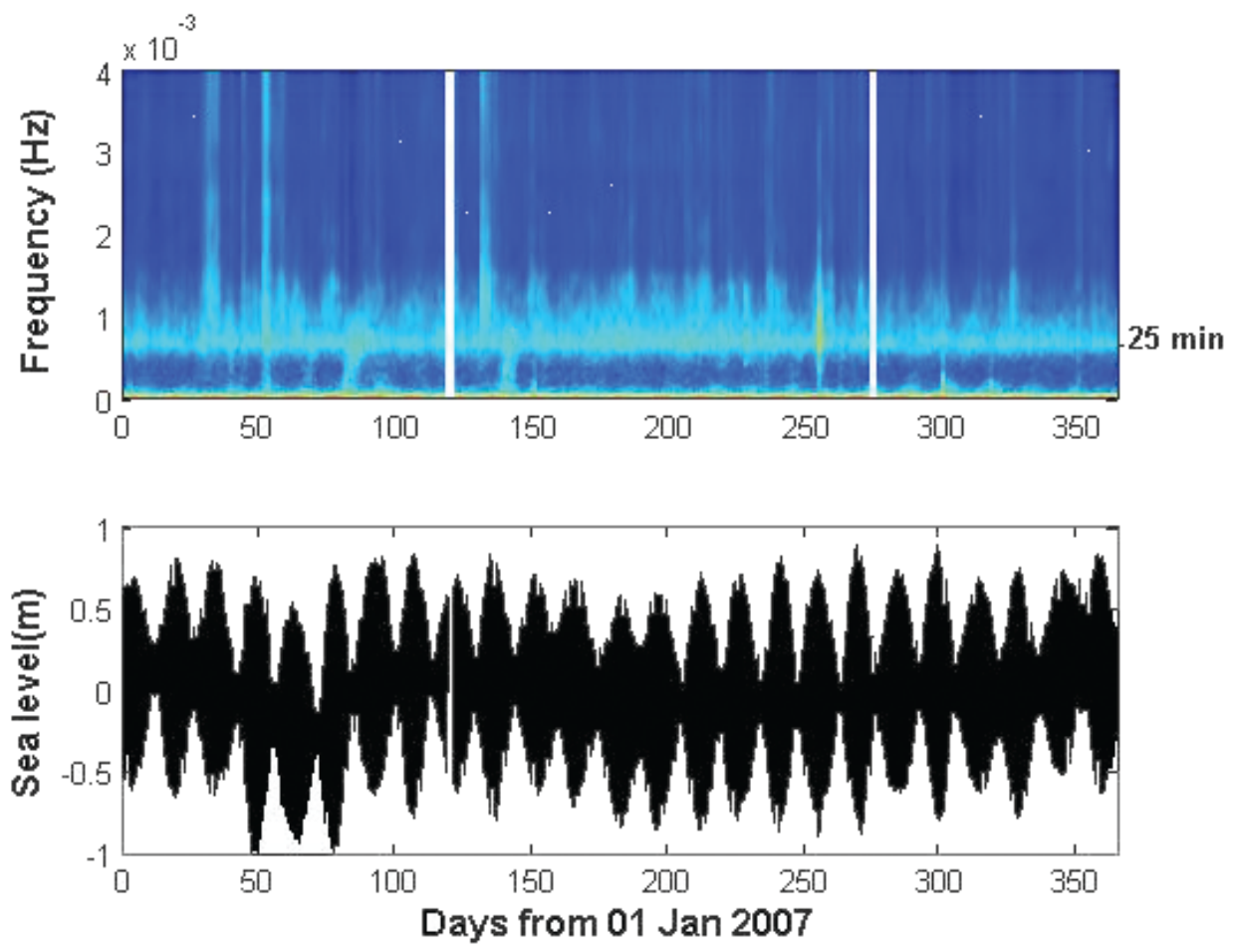

Fig. 8. Time-spectrum plot for Port Mathurin inner harbour 2007

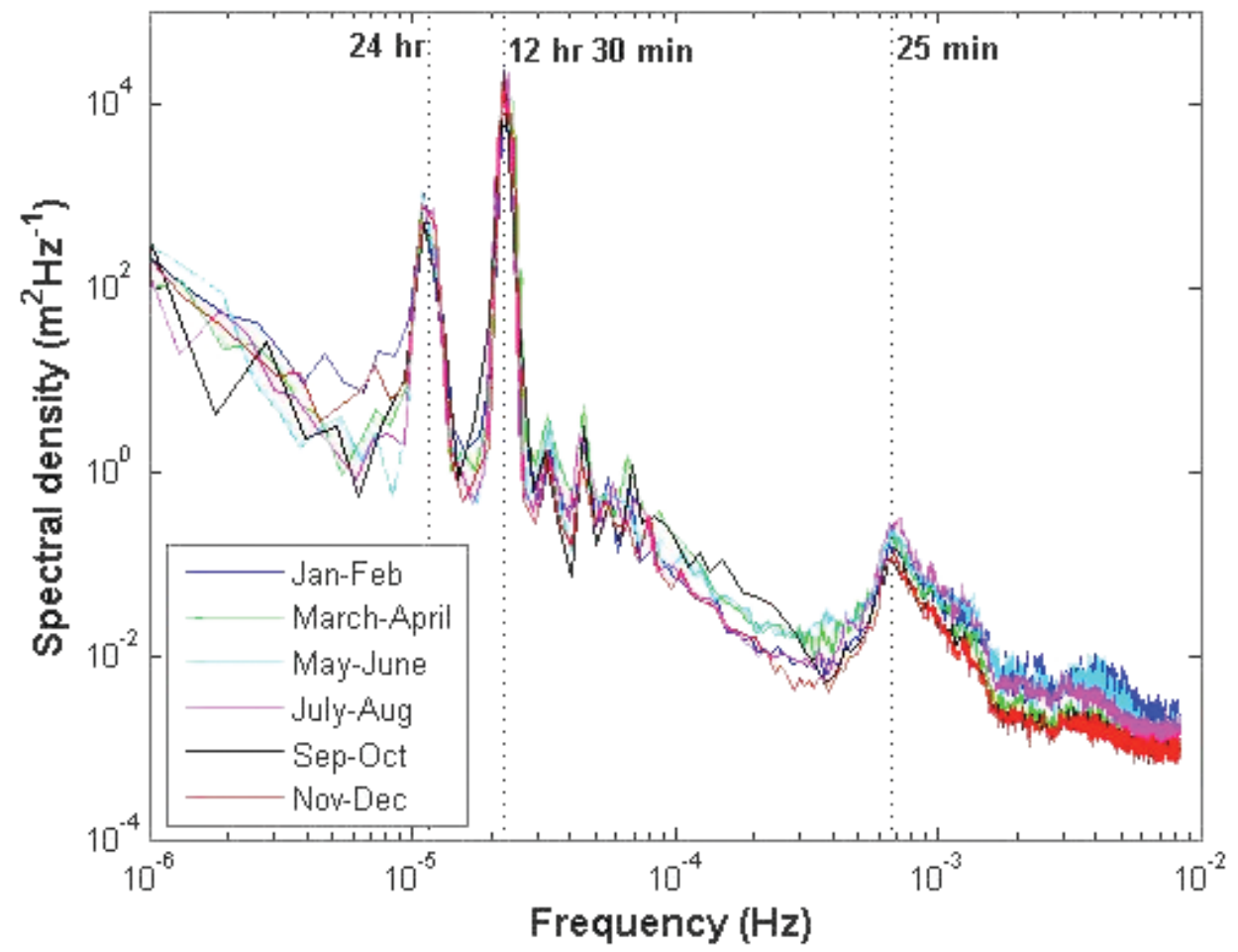

Fig. 9. Seasonal variations of the seiche spectrum at Port Mathurin 


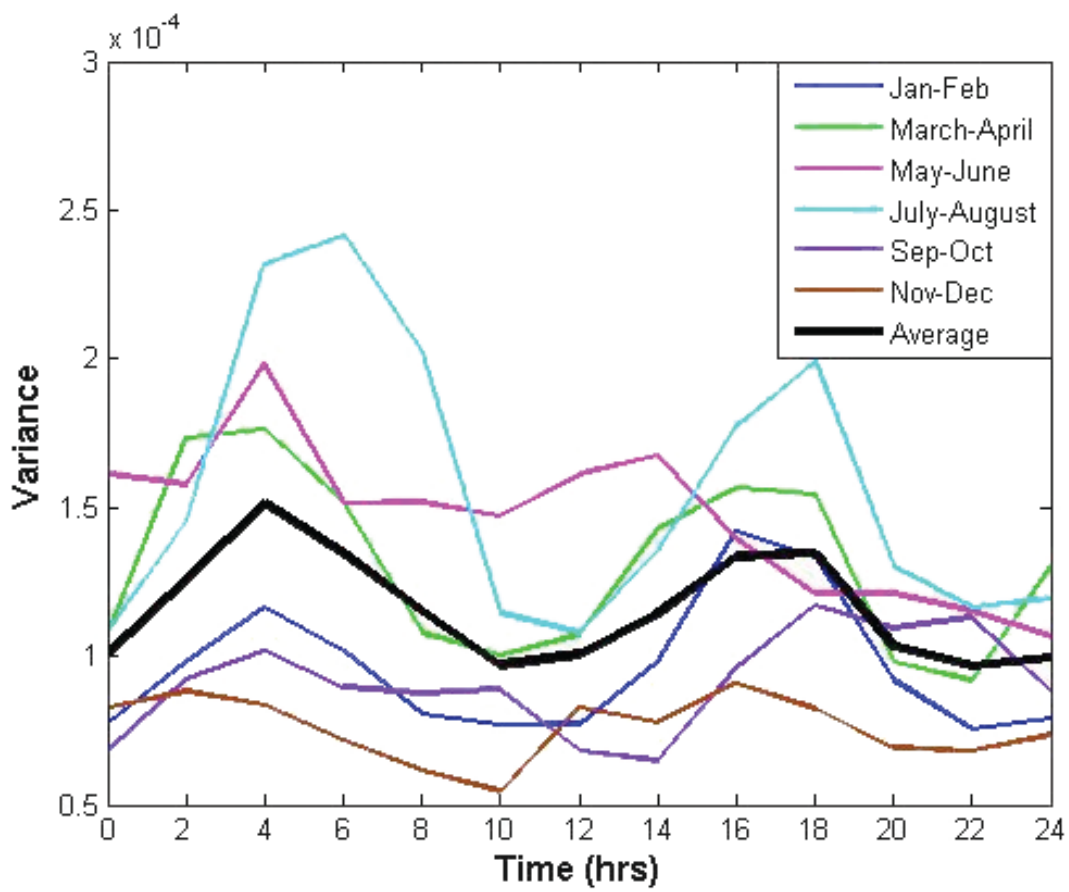

Fig. 10. Daily variations of seiche amplitudes at Port Mathurin

Table 4. Summary of the main tidal harmonic components, from the longer-period analyses. Phases are relative to Greenwich meridian, in the usual tidal convention. $K_{1}, M_{2}$ and $S_{2}$ are the principal lunar/solar diurnal tide, principal semidiurnal tide, and the principal solar semidiurnal tide respectively

\begin{tabular}{|c|c|c|c|c|c|c|c|c|c|c|}
\hline \multicolumn{2}{|c|}{ Location } & \multirow[t]{2}{*}{ Time } & \multirow{2}{*}{$\begin{array}{l}\text { Analysis } \\
\text { period }\end{array}$} & \multirow{2}{*}{$\begin{array}{c}\text { Mean } \\
\operatorname{depth}(\mathrm{m})\end{array}$} & \multicolumn{2}{|c|}{$\mathbf{K}_{1}$} & \multicolumn{2}{|c|}{$\mathbf{M}_{2}$} & \multicolumn{2}{|c|}{$\mathbf{S}_{2}$} \\
\hline & & & & & $\mathbf{H}(\mathbf{m})$ & $\mathbf{G}^{\circ}$ & $\mathbf{H}(\mathbf{m})$ & $\mathbf{G}^{\circ}$ & $\mathbf{H}(\mathbf{m})$ & $\mathbf{G}^{\circ}$ \\
\hline \multirow[t]{2}{*}{ Port Louis } & $\begin{array}{l}\text { Fanfaron } \\
\text { Inner harbour }\end{array}$ & 2002 & Year & 1.72 & 0.062 & 65.2 & 0.144 & 274.0 & 0.093 & 279.1 \\
\hline & Outer Beacon & Aug-Sept 2002 & Month & 24.3 & 0.059 & 70.3 & 0.155 & 267.4 & 0.117 & 272.0 \\
\hline \multirow[t]{2}{*}{ Blue Bay } & Inner Harbour & Dec-2002 & month & 15.2 & 0.062 & 89.2 & 0.265 & 250.8 & 0.163 & 271.4 \\
\hline & Outer & Dec-2002 & month & 21.1 & 0.061 & 86.8 & 0.260 & 242.9 & 0.158 & 265.0 \\
\hline \multirow{2}{*}{ Port Mathurin } & Inner Harbour & 2002 & year & 1.91 & 0.055 & 95.3 & 0.401 & 256.1 & 0.250 & 282.0 \\
\hline & Outer & July-2002 & 3-months & 22.9 & 0.050 & 94.0 & 0.400 & 255.1 & 0.255 & 280.0 \\
\hline
\end{tabular}

tidal ranges is approximately 4.5 in both places, compared with 2.7 for the Equilibrium Tide. At Port Mathurin, the differences between the amplitudes and phases of $\mathrm{M}_{2}$, the principal lunar semi-diurnal component, in the harbour and outside in the open ocean, are small. However, at Port Louis the inner harbour tides are $6.6^{0}$ or 13 minutes later than outside the harbour, and there is a small reduction in semi-diurnal tidal amplitudes. These values can be compared favourably with earlier values used in the Admiralty Tide Tables, as shown in Table 5 (converted from local time (-0400) to GMT).
The tides around the island of Mauritius have significant variations compared with the main site at Port Louis. For example, the tides at Blue Bay are substantially larger and occur some 50 minutes earlier than at Port Louis; the inner Blue Bay tides are 16 minutes later than outside the Bay.

Although the short periods of simultaneous analyses could not be used for determining tidal time differences accurately because of the nontidal variability, the approximate differences in tidal range can be estimated by regressing the observations at pairs of sites. Table 6 shows the 
Table 5. Comparisons of the Admiralty Tide Tables tidal harmonic amplitudes and phases, and the new 2002 analuses

\begin{tabular}{lllcccccc}
\hline \multicolumn{2}{c}{ Location } & Time & \multicolumn{2}{c}{$\mathbf{K}_{1}$} & \multicolumn{2}{c}{$\mathbf{M}_{2}$} & \multicolumn{2}{c}{$\mathbf{S}_{2}$} \\
& & $\mathbf{H}(\mathbf{m})$ & $\mathbf{g}^{\circ}$ & $\mathbf{H}(\mathbf{m})$ & $\mathbf{g}^{\circ}$ & $\mathbf{H}(\mathbf{m})$ & $\mathbf{g}^{\circ}$ \\
\hline Port Louis & Fanfaron & & & & & & & \\
& Inner harbour & $\mathbf{2 0 0 2}$ & $\mathbf{0 . 0 6 2}$ & $\mathbf{6 5 . 2}$ & $\mathbf{0 . 1 4 4}$ & $\mathbf{2 7 4 . 0}$ & $\mathbf{0 . 0 9 3}$ & $\mathbf{2 7 9 . 1}$ \\
& ATT & & & & & & \\
& & GMT & 0.06 & 65 & 0.14 & 271 & 0.09 & 275 \\
& & ATT - 0400 & & 125 & & 27 & & 35 \\
Port Mathurin & Inner Harbour & $\mathbf{2 0 0 2}$ & $\mathbf{0 . 0 5 5}$ & $\mathbf{9 5 . 3}$ & $\mathbf{0 . 4 0 1}$ & $\mathbf{2 5 6 . 1}$ & $\mathbf{0 . 2 5 5}$ & $\mathbf{2 8 2 . 0}$ \\
& & ATT & & & & & & \\
& & GMT & 0.05 & 97 & 0.41 & 256 & 0.250 & 284 \\
& & ATT - 0400 & & 157 & & 12 & & 44 \\
\hline
\end{tabular}

Table 6. Amplification of tides at sites around Mauritius, relative to Port Louis Inner Harbour (Fanfaron)

\begin{tabular}{lc}
\hline & $\begin{array}{c}\text { Scaling factor to Port Louis } \\
\text { (inner harbour) }\end{array}$ \\
\hline Grand Gaube & 1.39 \\
Blue Bay (inner) & 1.49 \\
Flic en Flac & 1.15 \\
Port Louis (outer) & 0.99 \\
\hline
\end{tabular}

amplifications relative to the Port Louis standard (inner harbour $=1.0$ ). The Blue Bay amplitudes are $49 \%$ larger than Port Louis standard; while at Grand Gaube, the tides are $39 \%$ larger. Even as close to Port Louis as Flic en Flac, the tidal ranges are $15 \%$ bigger. The regression process is too approximate to distinguish the small amplitude differences inside and outside the Port Louis harbour (1\%), established by the longer-period tidal analyses in Table 4.

For Rodrigues the amplifications compared with Port Mathurin are shown in Table 7. Because the island is smaller the ratio differences from unity are also smaller, the greatest difference being an amplification of $10 \%$ on the south of the island, at Mourouk.

\section{DISCUSSION}

In open basins, seiches can occur as lateral oscillations reflecting from the sides of the basin or as longitudinal oscillations between the head and mouth of the basin. They are equivalent to seiches in a closed basin with a node formed at the open end
Table 7. Amplification of tides around Rodrigues, relative to Port Mathurin, Inner Harbour

Scaling factor to Port Mathurin (inner harbour)

\begin{tabular}{ll}
\hline Grande Passe & 0.98 \\
Passe Demi & 0.94 \\
Mourouk & 1.10 \\
\hline
\end{tabular}

of the basin and an antinode at the head. This results in the formation of 'quarter wave resonances'. The seiche period in this case can be calculated using a modified version of Merian's formula:

$T=\frac{4 L}{(2 n-1) \sqrt{g h}}$

Or, for the fundamental mode $(n=1)$ in a basin of non-uniform depth, Du Boys' equation (Giese et al., 1990) can be used:

$T=4 \int_{0}^{L} \frac{d x}{\sqrt{g h(x)}}$

where $\mathrm{L}=$ length of basin; $\mathrm{h}=$ depth of water in basin; $n=$ number of nodes.

When this formula is applied for Port Louis, there are no (or very small) oscillations at the gauge outside the harbour at the period of 20 minutes. Therefore, it seems that Port Louis harbour acts as a quarter wave resonator with a node formed at the mouth of the harbour and an antinode at the head of the harbour (where the main harbour gauge is located at Fanfaron). If it is assumed, from harbour information, that the harbour is made up of two sections from mouth to head, with one section 13 $\mathrm{m}$ deep and $2.24 \mathrm{~km}$ long; the other $6 \mathrm{~m}$ deep and $0.4 \mathrm{~km}$ long, then; 
For the mouth section, of depth $=13 \mathrm{~m}$, length $=$ $2.24 \mathrm{~km}$;

speed of wave $=\sqrt{g h}=\sqrt{9.8 \times 13}=11.2 \mathrm{~ms}^{-1}$

time to travel distance $=2240 / 11.2=200 \mathrm{~s}$

While for the head section, of depth $=6 \mathrm{~m}$, length $=0.4 \mathrm{~km}$;

speed of wave $=\sqrt{g h}=\sqrt{9.8 \times 6}=7.7 \mathrm{~ms}^{-1}$

time to travel distance $=400 / 7.7=52 \mathrm{~s}$

The total time taken to travel the distance is 252 seconds - equivalent to a quarter wave. Therefore, the fundamental seiche mode for Port Louis Harbour $=252 \times 4=1008 \mathrm{~s}=16.8$ minutes.

For Port Mathurin, assuming a constant depth channel of length of $8 \mathrm{~m}$ and a length of $1.8 \mathrm{~km}$ gives a wave speed of $8 \mathrm{~ms}^{-1}$ and a travel time of 225 seconds. This is equivalent to a period of 15 minutes.

The seiche periods in practice, have been found to be generally longer than those calculated for the idealized situation. This can be accounted for by friction; loss of some energy to the deep sea though the mouth; and inertia of water at the mouth of open basins. Inertia of water at the mouth causes seiches to have longer periods than those calculated for the idealized case. For example, for a fully open square harbour, the seiche frequency can be a third smaller than the idealized case (Chapman et al., 1990). Recognising this constraint, the theoretical and observed seiche periods at both Port Louis and Port Mathurin are consistent with quarter-wave resonance.

The energy that sustains the observed oscillations could come from several sources. These include seismic disturbances, wind stress, pressure fronts, and internal waves, as well as swell and tidal changes. Given the sustained nature of the seiching it seems possible, as the only continual available forcing, that internal waves could be responsible The natural period of internal vertical oscillations, Brunt-Väisälä frequency is estimated at only one or two minutes, much less than the observed seiche periods. Measurements of internal wave activity, for example with a thermistor chain, offshore of the harbours, would be necessary to investigate the more exact nature of the forcing.
Figures 11 shows that here are no apparent links with the spring-neap tidal cycle at Port Louis, but Figure 12 shows that there are links at Port Mathurin. Note that the range of tides at Port Louis is relatively small. At Port Mathurin the average seiche range at spring tides, $0.03 \mathrm{~m}$, is about half the $0.06 \mathrm{~m}$ range at neap tides. Such links between seiche energy and the spring-neap tidal cycle have been observed elsewhere (Chapman and Giese, 1990) and attributed to tide-generated internal wave propagation from distant sources. However, Figure 12 also shows that the seiche ranges at Port Mathurin have a clear pattern within the individual semi-diurnal tidal cycle, especially at neap tides, when the largest seiches are observed 4 to 8 hours after high water, that is, around the time of tidal low water level. This implies that local channel dynamics, for example the tidal currents, may locally affect seiche amplitudes. The twice-daily changes in seiche amplitude at Port Mathurin, shown in Figure 9 could also be related to this spring-neap dependence, because spring tides occur at the same times in the day.

\section{CONCLUSIONS}

The principal aim of this study was to investigate the seiching signals in Mauritius and Rodrigues, and in particular, to establish whether these signals are present around the two islands, rather than only at the permanent tide gauge sites. Other questions addressed included whether there is any coherence in the signals; any relationship between the signals and the spring/neap cycle; and any favoured periods of oscillation.

Seiching is found to be a local phenomenon, confined to individual coastal locations and harbours. There are different seiche periods at two nearby sites on Mauritius, and at two nearby sites on Rodrigues. At many sites no significant seiching occurs. The two main harbours, Port Louis and Port Mathurin, have the biggest seiches and these are present through all the data and at all seasons. The main periods of 20 and 25 minutes at the two main sites are close, but significantly different. One of the initial inspirations for this work was the possibility that, from observations of the analogue records, the seiches may have the same period for the two sites, 

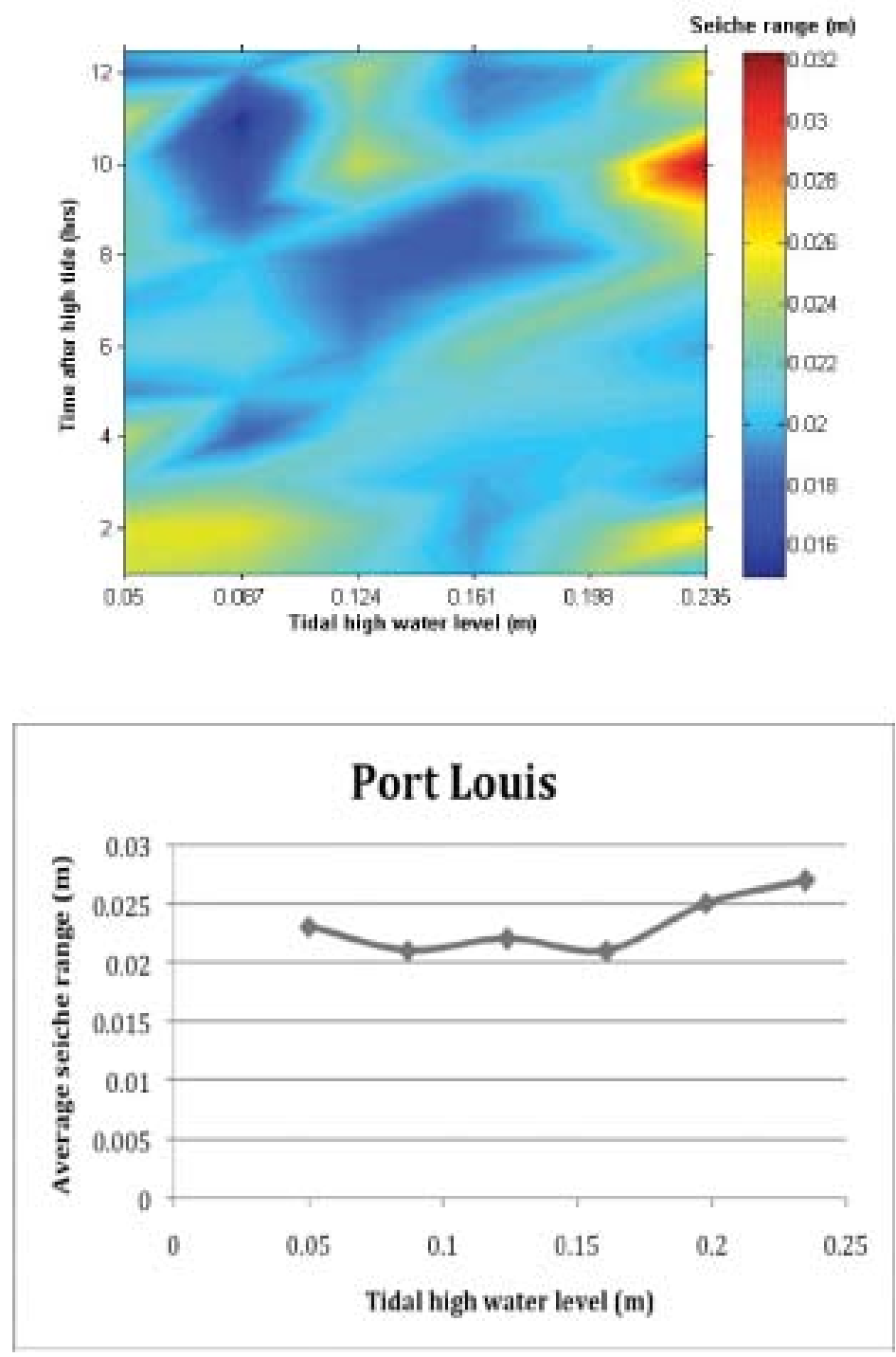

Fig. 11. Variations of 20-minute-seiche ranges at Port Louis as a function of the tidal range. Levels are relative to mean sea level

and were perhaps linked through external forcing at the same period. However, that is not the case, and other periods are favoured elsewhere around the islands.

The spring-neap influence on seiche ranges that has been observed elsewhere, is also found at Port Mathurin, but not at Port Louis. Seiche amplitudes at Port Mathurin are greatest at low water during neap tides. This relationship to the tidal phase in the local semi-diurnal tidal cycle suggests that the dynamics of the tidal flows in the channels may be an influence on seiche propagation and ranges
- something that could be further investigated by numerical modelling.

As an example of the application of numerical modelling to identify forcing mechanisms, a twodimensional modelling study.of seiches around Sri Lanka is in preparation (EMSW). The analysis of high frequency tide gauge records from different parts along the Sri Lanka Coast reveals that the different forcing mechanisms could be responsible for the west and east coast seiches. Fortnightly and seasonal variations of seiche amplitudes are clearly visible from east and southeast coasts tide 

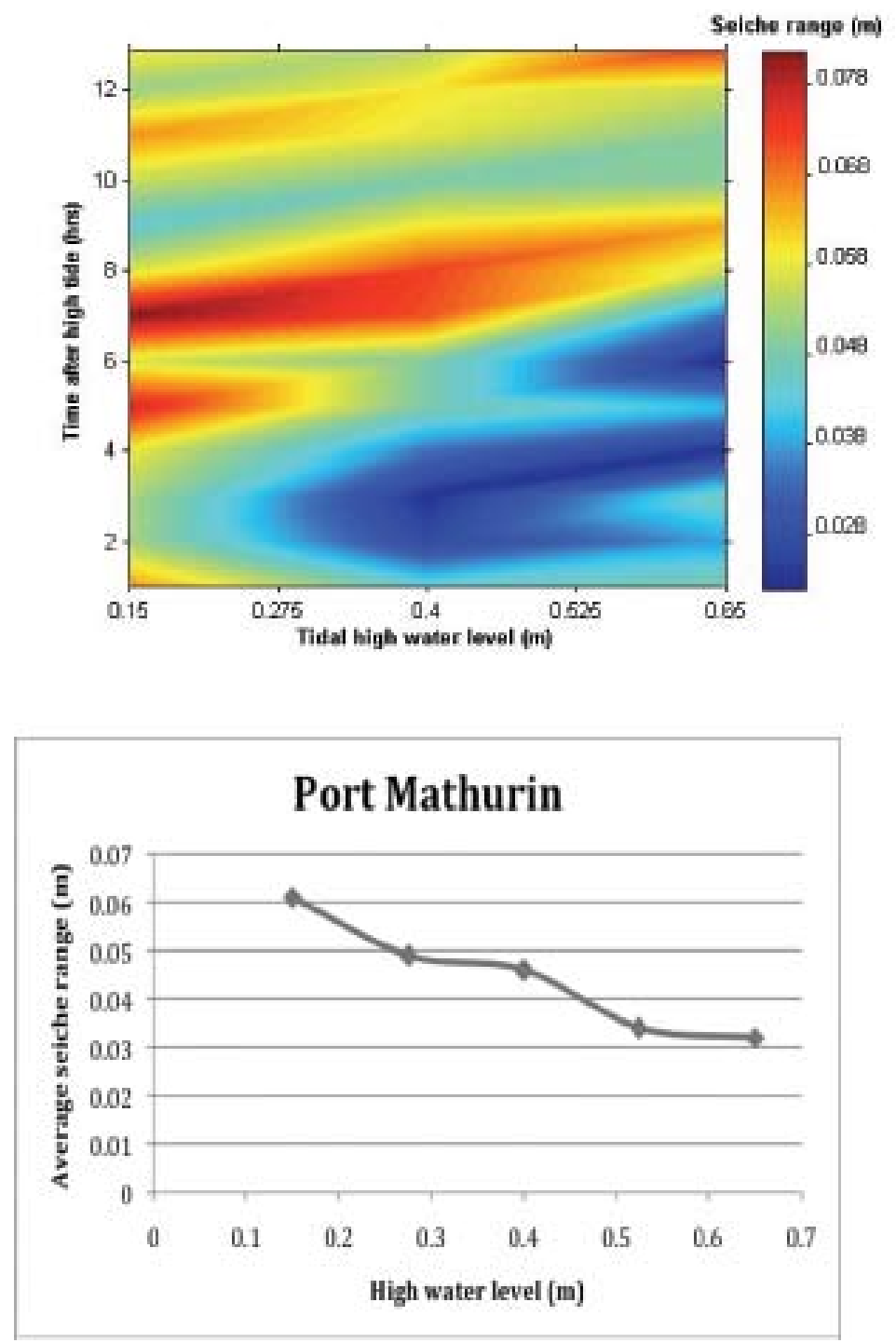

Fig. 12. Variations of 25-minute-seiche ranges at Port Mathurin as a function of the tidal range. $0.65 \mathrm{~m}$ is the Mean High Water Spring level. Levels are relative to mean sea level

gauge records. The seiche amplitudes are large approximately 6 days after spring tide throughout the year and maximum amplitudes have been observed during months of March-April and October-November. There is no visible fortnightly and seasonal variation of seiche amplitudes in west coast tide gauge records. However, they show good correlation with daily atmospheric pressure variation suggesting that the seiches on the west coast could be forced by atmospheric forcing. This work supports the idea that a wide range of different forcing processes can be responsible for triggering seiching, with different mechanisms dominant in different locations.

Large amplitude internal waves are known to be generated around the Mascarene Plateau in the Indian Ocean and to travel long distances. Hence the presence of seiching signals around several islands of the Indian Ocean region could be due to largescale processes occurring in the Indian Ocean. The extent and nature and energising of these seiching phenomena calls for further investigation. 
Acknowledgements-This work was supported by our parent Institutes. EMSW acknowledges support from an Intergovernmental Oceanographic Commission Fellowship to work at the Proudman Oceanographic Laboratory, Merseyside UK, in 2007, when many of the analyses were completed. In Mauritius we were helped by the Mauritius Port Authority, the National Coast Guard, and by the Mauritius Meteorological Services, who also assisted on Rodrigues. In Rodrigues the Shoals Rodrigues Laboratory provided additional substantial diving and other operational support. Philip Woodworth's encouragement and help is gratefully acknowledged.

\section{REFERENCES}

Allison, H and Grassia, A (1979). Sporadic Sealevel Oscillations along the Western Australian Coastline. Australian Journal of Marine and Freshwater Research 30, 723-730.

Araújo I., (2005) Sea Level variability: examples from the Atlantic Coast of Europe. unpublished PhD Thesis, National Oceanography Centre, Southampton.

Chapman, S. and R.S. Lindzen (1970): Atmospheric Tides. D. Reidel, 200pp.

Chapman D C and Giese G S (1990) A model for the generation of coastal seiches by deep sea internal waves. Journal of Physical Oceanography, 20, 1459-1467.
Giese G S, Chapman D C, Black P G, and J A Fornshell (1990) Causation of large-amplitude coastal seiches on the Caribbean coast of Puerto Rico. Journal of Physical Oceanography, 20, 1449-1558.

Giese G S and Chapman D C (1993) Coastal seiches. Oceanus, Spring 1993, 38-46.

Morison M and Imberger J (1992) Water level oscillations in Esperance Harbour. Journal of Waterway, Port, Coastal and Ocean engineering, 118, 352-367

Pattiaratchi C B, Wijeratne E M S, (in prep.) Tide gauge observations of the 2004-2007 Indian Ocean Tsunamis from Sri Lanka and Western Australia. Submitted to Pure and Applied Geophysics, Jan 2008.

Pugh, D T (1979) Sea levels at Aldabra Atoll, Mombasa and Mahe, western equatorial Indian Ocean, related to tides, meteorology and ocean circulation. Deep-Sea Research, 26A, 237-25.

Rabinovich A. B. and Thomson R.E. (2007) The 26 December 2004 Sumatra Tsunami: analysis of tide gauge data from the world ocean Part 1. Indian Ocean and South Africa. Pure appl. Geophys. 164, 261-308.

Woodworth P L, Aarup T, Merrifield M, Mitchum GT, and Le Provost C (2003) Measuring progress of the Global Sea Level Observing System. EOS, Transactions of the American Geophysical Union 84(50): 16 December 2003. 